Биљана С. Самарџић*

Универзитет у Источном Сарајеву

Филозофски факултет Пале

Катедра за србистику

https://doi.org/10.18485/ai_zsjoski.2019.2.ch5

811.163.41'373

821.163.41.09

\title{
МЈЕСТО СЛАВЕНИЗАМА У ЈЕЗИКУ КЊИЖЕВНОСТИ
}

У раду смо посматрали улогу и функцију славенизама у различитим књижевним жанровима. Сагледавањем њихове заступљености, те мјеста и функције у књижевном тексту, представили смо један преглед од предвуковског стандардног језика до савременог српског језика и тиме показали праву ризницу употребе славенизама као поетске лексике у језику књижевности. Под термином „славенизми” подразумијевали смо ријечи словенског поријекла, које припадају руском књижевном језику, рускословенском, српскословенском, славеносрпском и наравно старословенском/црквенословенском; али не припадају српском народном језику.

Кључне ријечи: славенизми, књижевни језик, језик књижевности.

\section{1. Уводне напомене}

Иако славенизми данас не улазе у активни корпус српскога језика, рад ће јасно показати да праћењем и проучавањем славенизама, ексцерпираних из различитих књижевних форми, многи језички изрази који су

* vsbiljana@gmail.com 
настали еволуцијом према српскословенском, рускословенском/црквенословенском, и на тај начин обогатили језик књижевности и у предвуковско и садашње вријеме, „живе” и данас и богате српски језички корпус и дио су језика књижевности. Другим ријечима, под термином „славенизми” подразумијевамо ријечи које су словенског поријекла и које припадају рускословенском, руском књижевном, славеносрпском и српскословенском језику, али не припадају српском народном језику. Термин је обичан у новијој славистичкој литератури (Толстој 1977, Младеновић 1984, Вукомановић 1988, Суботић 1989). И Вук Стефановић Караџић је упућивао (1826) на особености славенизама и њихово поријекло, указујући на неопходност посрбљавања, при чему је за примјер узимао мноштво таквих 'посрбљених речи' из Собранија архимандрита Јована Рајића (Караџић 1969: 53-60). Није се Вук само у овом тексту осврнуо на ову лексику. У Преgіовору свог превода Новоі завјет̄ $а$, Вук напомиње да је задржао 49 ријечи које се у народном језику не говоре, али се разумију, и 47 које су посрбљене. ${ }^{2}$ То су „славенске” ријечи које су из рускословенског фонда, или посрбљене ријечи или ријечи које писци сами смишљају за потребе својих дјела (Караџић 1974: 16). Вуку нису сметале ријечи које су се вијековима усталиле у источнохерцеговачком говорном типу, као нпр.: васкрснушич, Вас-

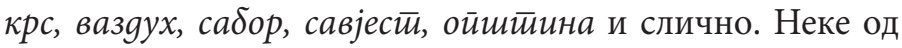

2 То су ријечи: боїобораи, боїомрзаи, боїомрски, среброљубаи, сииријелаи, gвојезичан, јеgинодушан, нелицемјеран, крајеуіалан, неблаїо-

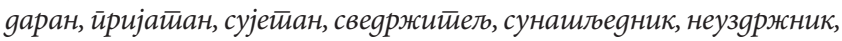
тьубазнииа, нельубазнииа, тицемјерје, невјерје, сујевјерје, изобилье, обите, братиољублье, човјеколублье, среброљублье, искушете, нейо-

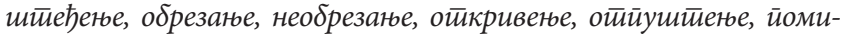

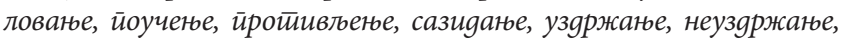

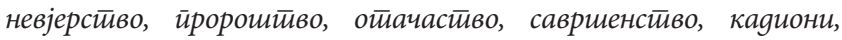

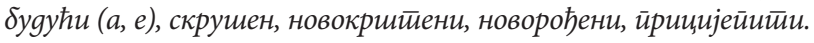


ових ријечи се данас и не осјећају као архаичне нити као црквенословенске (вазgyx, сушичина). Дакле, ријечи као свешиченик, Васкрс и слично Вук је унио у Срйски рјечник „од којих су неке српскословенски маркиране док су неке неутралне, тј. истовремено чине одлику и рускословенског и поменутог старог српског црквеног и књижевног језика" (Младеновић 1989: 63).

У научној литератури примијећен је један „шаролики” терминолошки апарат у вези са одређењем и статусом славенизама. Тако нпр. Борис Унбегаун у Почеицма книжевноі језика коg Срба користи термине руски славенизми, славенизми, русизми - и разликује двије категорије русизама (лексичке и морфолошке). При томе Унбегаун када говори о славенизмима, у ствари мисли на елементе рускословенског језика и пише: „Да би један руски текст добио право грађанства у српској књижевности, требало га је славенизирати” (1995: 63). Због тога Зорић и констатује: „Уношење елемената рускословенског језика чинило је зато језик разумљивијим, а с друге стране, ти исти елементи приближавали су српски народни језик језику цркве и високом стилу, градећи тиме средњи стил, односно Civil-Sprache Миријевског” (2018: 17). Код Никите И. Толстоја (1977) постоји подјела на славјанизме и русизме, што и има оправдање код Руса јер је ту ријеч о лексици из домаћег, тј. руског насљеђа и црквенословенског. Тако се код њега појављују термини руско-славенизми, словенизми који (ни)су србулькоі,

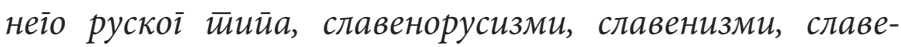
низми руске обојеностии, ирквенословенизми - којима се обиљежавају славенизми који имају руску компоненту. Истина, Толстој даје и термин србизам, „што би требало да попуни одговарајуће место у пару русизам/ славенизам из руског језика" (в.: Зорић 2018: 17). Данко Шипка даје подјелу на: црквенославенизме (божанстиво,

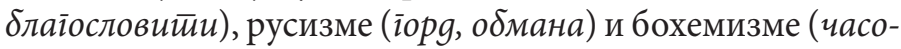


йuc, учинак) (1998: 86-87). Павле Ивић на сличан начин посматра славенизме као нестандардне изразе у српском народном језику, али које су као позајмљенице из руског и рускословенског егзистирале у нашој књишкој писмености. При томе истиче управо мјешовите, хибридне форме у којима су се „измијешале” форме руске и српске редакције старословенског, руског књижевног језика и добијени су облици који у ствари не одговарају конкретном стању ни у једном од изворних језика (Ивић 1998: 134-135). Можда је понајбоље одређење славенизма дао Светозар Стијовић (1992) и при томе је и хибриде ријечи укључио као лексику која је дио славеносрбизама, и није одвојена од славенизама. Он проширује опсег славенизама, не само схватањем да су то ријечи из црквенословенског, руског језика, српске и руске редакције старословенског, већ и кованицама које садрже елементе славенизама. Да би све то одредио и дефинисао, Стијовић је указао и на проблематику идентификовања самих славенизама - „да ли је одређена лексема рускословенског или руског порекла и, уколико нема карактеристичних фонетских црта, да ли лексема припада руској или српској црквеној традицији” (из: Зорић 19-20). Ми смо у раду препознавали славенизме на основу сљедећих елемената:

1) провјера у рјечницима: Даничић, Рјечник из књижевних сииарина срӣских $(1863,1864)$; СТАРОСЛОВЯНСКИЙ СЛОВАРЬ (по рукописям Х-XI веков) (1994); Петковић, Речник ирквенословенскої језика (1935); Ајдуковић, Конйакйолошки речник аgаййације русизама, у осам словенских језика (2004); Речник срйскої језика Матичие срйске (2007) и Велики речник ситраних речи и израза (Клајн, Шипка, 2012).

2) препознавање славенизама преко граматичког критеријума, тј. преко фонетских црта различитих језика у једној ријечи. Дакле, у раду смо се базирали само на фонетске црте; док смо морфолошке оставили за друга истраживања. 
Када се погледа књижевни опус српских писаца предвуковског времена, јасно је да су славенизми били изражена вертикала развитка књижевног језика те епохе и језика писаца. Испитивањем књижевнојезичких идиома појединих књижевних стваралаца довела нас је и у предстандардни период у развоју српског књижевног језика. „Реч је о лексемама књишке провенијенције, пре свега апстрактног значења, или терминима, којих у лексичком фонду народног језика није било. Будући да се изразит пуризам према овом слоју лексике појављује тек с појавом Вука и његових следбеника, културни трудбеници краја 18. и почетка 19. века који нису припадали овој новој вуковској струји сматрали су потпуно природним позајмљивање лексике из оног језика који је у то време био један од културно најдоминантнијих и структурно најближих српском. Ове лексеме, управо из тог разлога, представљају основни кључ за идентификацију како језичког израза појединог писца те епохе тако и његовог става у погледу структуре књижевног језика" (Зорић 2018: 13-14). Узмимо за примјер славенизме у трагедијама и комедијама Јована Стерије Поповића. Славенизмима и уопште језиком у Стеријиним дјелима бавили су се многи научници (Клаић 1972, Каленић 1981, Младеновић 1982, Ивић 1998, Јерковић 1991, Анђелковић 2003 , Суботић 2006, Зорић 2018). Грађу смо ексцерпирали из два драмска текста, тј. из Стеријине прве објављене трагедије Светиислав и Милева и комедије Лажа и йаралажа, и на њима ћемо показати и улогу славенизама у трагедији и комедији кроз обрисе фонетског аспекта на подлози како је С. Стијовић анализирао славенизме код Његоша (1992). Да славенизми и данас богате језик књижевности показаћемо на примјерима поезије Рајка Петрова Нога

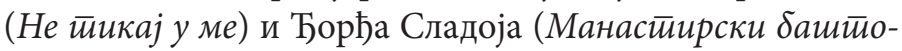
ван), чији су многи пјеснички изрази саткани посебно по угледу на црквенославенизме, као и романа Лимунација 
y Ћелијама Радована Белог Марковића, у којем разобличеност животног апсурда, осликану кроз црну хронику једног уклетог мјеста, писац врши невјероватне језичке транспозиције, па самим тим и славенизми имају своје упориште. Тако ћемо кроз различите књижевне жанрове показати и улогу и функцију славенизама у обрађиваном корпусу.

\section{2. Подјела славенизама (фонетски аспект)}

a) Славенизми заједнички српској

и руској редакцији старословенског језика

У овој групи обрадићемо ону лексику која је заједничка овим редакцијским језицима, а која је ушла у славеносрпски језик. То су превасходно ријечи са групом жg и суфиксом -ије. Пронашли смо многобројне потврде за ову лексику: наgежgа (СиМ 167), нужgа (СиМ 168), најйрежgе (ЛиП 69), иррежgе (ЛиП 69), увеселеније (СиМ 192), очајаније (СиМ 194), изреченије (ЛиП 33), восйитианије (ЛиП 45), созаклетиије (ЛиП 76), мирјеније (ЛиП 76), блаїојјејаније (ЛиП 77), gруіојачије (ЛиП 80), бешчиније (СиМ 163), високороgије (СиМ 165), ирреgисловије (ЛуЋ 27), збииичје (Лућ 30), сохраньеније (Лућ 31), йисаније (Лућ 45), нечастије (Лућ 58), узваније (Лућ 58), иррисојуженије (Лућ 60), униније (Лућ 65), олежgи (ЛуЋ 67), межgу (ЛуЋ 97), нечасиввије (Лућ 102), ӥреірешеније (Лућ 195), наgежgу (Лућ 117), сосйојаније (Лућ 131), с нужgним (Лућ 143), ужgраку (Лућ 183) и слично. Језик књижевности пјесника такође је богат рускославенизмима и српскословенизмима. Тако су код Нога пронађени облици: нишчи: Kag је нишчи био тивој службеник Боже / Пречисйа Тројиче ииеби је све знано / Како сииече блаїо и ии юеїа йоїибе (НТУМ 21); и код Сладоја: Нека се и на нишчеі̄ їосйоgюа милости иррелије (МБ 19), Високо наg 
іраgом gа йе нишчи виgе (МБ 73), И маgа јесмо нишчи иако живимо йсећи (МБ 91) и слично. ${ }^{3}$

Без обзира на временску дистанцу, славенизми који су заједнички српској и руској редакцији првог књижевног словенског језика и данас учествују у језику књижевности, док у активном корпусу српског језика немају функцију јер се у језику књижевности они укрштају са другим дијахроним језичким слојевима и тако се осликавају и у модерној умјетности. Док у поезији Нога и Сладоја имају функцију управо приказивања старог стања, језичког и историјског богатог и сведеног, у прози Радована Белог Марковића имају сасвим другу димензију и улогу - они су симболизација апсурдности и свијета и времена изражене кроз сам језик. „Језик је, нема спора, главни јунак свих Марковићевих књига, а од 'Лимунације у Ћелијама' он се више и не јавља (само) као преносник неког стварног или имагинарног света, већ је језик сам свет. Свет је језик, и све је у језику, свет који тим језиком постоји не постоји нигде изван тог језика" (Пантић 2003: 19). На тај начин Радован Бели Марковић пише „роман о ничему”. Другим ријечима, Радовану Белом Марковићу овај спој лексике, заједничке српскословенској и рускословенској епохи, не служи да обиљежи, расвијетли, прикаже један заједнички моменат српског и руског народа и језика, већ да напише „роман о ничему” са свим апсурдностима ништавила.

б) Српскословенизми

Овдје превасходно подразумијевамо пексику са групом $и \bar{u}$ и српскословенски развитак йолуіласничкої знака. При томе смо за примјере узимали само оне

3 Ознаке: СиМ (Светиислав и Милева), ЛиП (Лажа и йаралажа), ЛуЋ (Лимунација у Ћелијама), МБ (Манастиирски баштиован), НТУм (Не тиккај у ме). 
лексеме код којих се група $и \bar{u}$ управо тако и графиј-

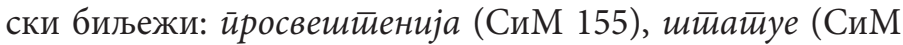
158), обшйе (СиМ 158), ишйе (СиМ 176), йросвешитеније (СиМ 160), буgуштии (ЛиП 73), восхишитеније (ЛиП 75),

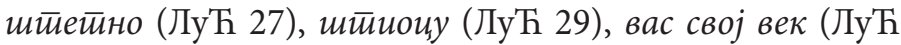
41), ваиррос (Лућ 56), шимиоции (ЛуЋ 64), шимију (Лућ 64), шимиои (ЛуЋ 64), вазнесене (ЛуЋ 76), кршичене (ЛуЋ 77),

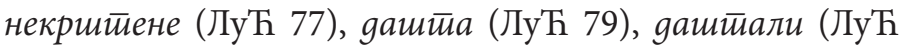
79), gашйане (Лућ 79), саілашавају (Лућ 89), вавек нейко (ЛуЋ 155) и слично. Наиме, познато је да у периоду XVIII и XIX вијека ова графема могла имати гласовну вриједност шч- што је било у складу са рускословенским и $\boldsymbol{w} \bar{u}$ - у духу српскословенског. Пронашли смо

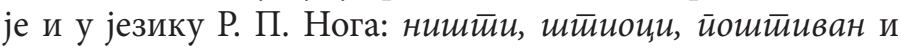
слично. Развитак полугласничког знака у $а$ је типична особина српскословенског (префикс сq у са): сајеgинитии (СиМ 159), саизволетии (СиМ 161). Ових примјера је мало, јер је овај рефлекс посвједочен и у примјерима из народног језика, те није само особина српскословенског. Славенизме са српскословенским гласовним особинама најлакше је препознати преко типичне српскословенске вокализације полугласничког знака у $а$. То чување групе ва, мјесто $y$, налазимо и код Сладоја: Нека вас васкрсло семе и йрећим сунием зіреје (МБ 112), и код Нога: вазgвиiох, васкрсара и слично. Умјесто ових славенизама: Аз раб

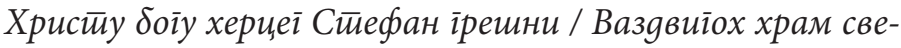
йом мученику Борђу (НТУМ 24) и Како немо йоју ко gва васкрсара (НТУМ 17), Ного је могао користити одговарајуће примјере из српског народног језика и да при томе сачува метар стихова. Ного је тако учинио, као и Сладоје, да би појачао литерарни израз. Префикс съ развио се у са тамо гдје је полугласнички знак по поријеклу био у слабом положају (савјей: стсл. съвьть, -а m - савјет, вијеће).

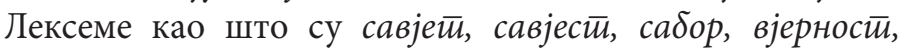
лукавстиво, сииворење као и неке друге ријечи које су 
означавале појмове углавном апстрактног значења, могу се објашњавати на начин да је ослонцем на рускословенски (руски црквени) језик, затим и на ондашњи руски књижевни, као и на српскословенски језик (мањим дијелом), славеносрпски књижевни језик ове споменуте лексеме позајмљивао из ових језика. Именице типа савјети и сабор су посрбљене на нивоу српскословенског језика. У ову групу примјера спадају и именице на -(a)u (<-qсq):

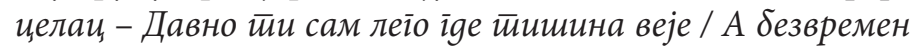
иелаи, иоравнава међе (13), сечаи: А ойкуg је gошо сећа се све блеђе / Мраморник и сечаи, жалобно нариса (13); казнац: А казнаиу Санку сесрита / А йостиави си белеї юен син Дабижив (22); и придјеви на -(a)н (<-ьнь): ірешан / неуиетиан и слично. Суфикси на $-(a)$ и и $-(a)$ u заједнички су и српскословенском и српском народном језику и овим суфиксима могле су бити србизиране и поједине руске лексеме - нароgаи. Типична особина српскословенског јесте чување групе чр: боіомначрйана ћирилска

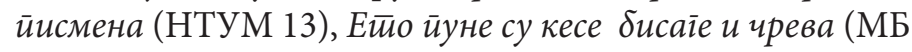
91) и слично (в.: Самарџић 2011).

в) Рускословенизми

У ову групу убрајамо оне славенизме који имају рускословенске или руске фонетске особине: група $и$, вокално $p$, рефлекс йолуїласничкої знака, те рускословенски рефлекс назала ӣреgнеї реgа.

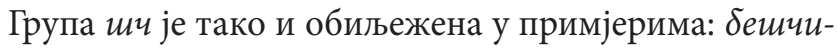
нија (СиМ 163), нешчастичје (СиМ 165), шчастичје (ЛиП 54), сокровишча (ЛиП 55), вјашчајши (ЛиП 59), gщчер (ЛиП 65) и слично. Највише ових примјера је у Лажи и иаралажи, односно у језику Алексе Голића. То је очекивано, јер је Стерија управо преко рускословенизама и градио карактеризацију самог лика Алексе Голића. Због тога је Стерија Алексин говор обогатио лексемама у којима се вокално $р$ и л праве по руском/рускословенском 
фонетском принципу. Тако Алекса изговара вокално р као секвенцу ер: Сербима (ЛиП 43), сербски (ЛиП 44), жеритва (ЛиП 50), серgце (ЛиП 55), совершио (ЛиП 59), совершено (ЛиП 77); али се овакви примјери јављају и у првој Стеријиној трагедији: жеритва (СиМ 168), жеріивовао (СиМ 171), жеритвуј себе (СиМ 172), иожеритвованем (СиМ 176) и слично. Ако нпр. узмемо само Лажу и йаралажу и језик Алексе и Марка, јасно увиђамо преко само вокалног $p$ однос једног лажног барона који покушава говорити узвишеним стилом и зато је код њега увијек Сер$\delta u н$, и једног домаћина - Марка, с друге стране, код којег је увијек Србин. Да би појачао ту дозу експресивности Марку ставља у уста народни језик, док Алекси - профињени и узвишени рускословенски. Александар Младеновић констатује: „Треба се овде задржати и на транскрипцији имена Сербинх, Сербљи, као и придева сербскіі и сл. (...) Наши људи су изговарали, несумњиво, поменуте речи и са ер и не само са вокалним p. То се у првом реду односи на писце, на школоване људе, на оне у чијем је образовању била присутна рускословенска, одн. руска језичка компонента. Сербин и Србин су биле свакако међусобно стилски диференциране: прва је припадала књижевном, а друга по правилу, српском народном језику иако се ова може срести и у писаним и у штампаним текстовима предвуковског и вуковског периода, и то нарочито у српском језичком контексту" (1979: 117-118). Тај однос је најбоље илустровати самим примјером из текста: Марко Алексу пита чистим народним српским језиком:

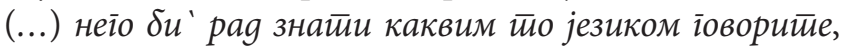
а Алекса му одговара: Ово је језик славјано-сербски; йо јести сербски, но йо ирравилима уілађен, којим су се највећи gухови као Сӣојковић, Вияаковић, Вујић и ироои у књиїама служили (ЛиП 44). Марку је чудноват Алексин језик, зато га и пита: Боїа вам, јестие ти ви Србин? АЛЕКСА: Прави, и йрозвишчем и йлеменем. Марко: Хм! А ја бих реко gа 
нистие баш иррави Србин (...) Ја вас не разумем, а ја сам јамчано йрави Србин, јер је моја родбина из Пожаревиа на ову стирану йрешла. Ал.: Да ви йрави Сербин јесйе, о йом

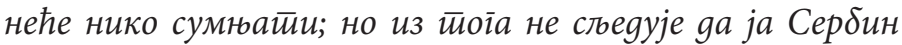
нисам; ионеже сам ја вјежестива ириобрео, вкус изобразио, чувстива уйончао (ЛиП 43).

Само из овог пасуса препознатљиво је да је славенизмима Стерија градио карактер ликова и тако показао да је преко говора, тј. језика јунака, правио идентификацију позитивних, домаћинских, добронамјерних ликова - с једне стране и негативних, жељних богатства и славе - са друге стране. Другим ријечима, језик којим се служе Алекса и Марко састоји се од два идиома. Један је онај који користи Марко, или Алекса сам у раз-

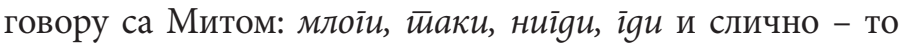
је српски народни језик војвођанских говора. Међутим, другим језиком говори Алекса у присуству других - то је језик затрпан славенизмима и „служи као маска” лажног представљања. То се види и употребом рускословенског фонетизма х > o, a q > e: воображавајући (СиМ 157), божестивени (СиМ 158), књижестиво (СиМ 159), художестиво (СиМ 159), воистиину (ЛиП 44), восӣитианије (ЛиП 45), восиичйана (ЛиП 77) и слично. У обје драме посвједочени су и примјери рускословенског и руског рефлекса назала предњег реда /ja/: вјашчајши (ЛиП 35), йамјай (СиМ 200), иритијажаватии (ЛиП 40), всјачески (ЛиП 51) и слично.

Овај тип славенизама пронашли смо и код Радована Белог Марковића: јазику (Лућ 28), ӣервом (Лућ 28), књижестиву (ЛуЋ 29), иерви (ЛуЋ 35), о осјелийсја се (Лућ 53), іречески (ЛуЋ 59), месјаи, (ЛуЋ 59), ашче (Лућ 60), серgиу (Лућ 60), книжесиива (Лућ 65), за йерво (ЛуЋ 66), gашчици (ЛуЋ 67), советиована (ЛуЋ 72), царстввујушчој (ЛуЋ 88), во времје (Лућ 104), совершавају (Лућ 117),

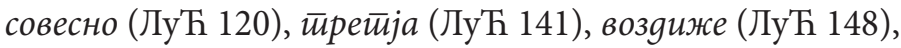
остијало (Лућ 181) и слично. Рускословенизми обогаћују 
језички инвентар Радована Белог Марковића у роману Лимунација у Ћелијама. Сви ликови овога романа помињу се као бивши, тј. смрт је њихова заједничка црта која индивидуализује јунаке. Зато овакву структуру романа прати и језик „који је истински уметнички преседан. Наглашавање вредности и важности тога језика у многоме одређује и природу критичког описа и тумачења свих Марковићевих романа" (Пантић 2003: 21). И тако Радован Бели Марковић готово митски осликава један крајолик, који је управо и његов родни завичај, и који из своје забачености и учмалости поробљава осјетљива бића која су актери овога романа. „Језик, притом, призива све појединачне отмености духа и животне ситуације, сво 'витештво патње' које происходи из човековог жалосног положаја у свету" (Продановић 2003: 33). Дакле, употребом рускославенизама Радован Бели Марковић приближава се говору нпр. Доситеја Обрадовића и тој баршунастој структури наше барокне књижевности и тако подвлачи своју намјеру да обликује посебне димензије свијета језиком у којем стварни или привидни „мними литерата Р.Б.М” пише своје трагање за почетком и суштином и своју жалопојку због патње на овоме свијету. На тај начин Радован Бели Марковић, као савремени српски писац, изграђује доминантан прозни текст проткан „шароликом” лексиком. Рускословенизми тако „оживљују”, али и „страдају” замјеном другим лексемама, исто као и Радованови јунаци заробљени између два свијета, тј. својим „запретеним значењима наново оживљавају један давни и древни говор и на тај начин, у вербалном суседству са савременим изразом, остварују се као носиоци изразите стилогене вредности" (Баук 2003: 104).

\section{г) Славеносрбизми}

Славеносрбизми представљају једну мјешовиту лексику која се одликује и елементима српског народног језика и особеностима српске и руске редакције ста- 
рословенског. О овој скупини ријечи посебно је писао С. Стијовић у студији посвећеној славенизма код Његоша, као и Александар Милановић који их разврстава у четири типа: рускословенски/руски + српски народни, рускословенски/руски + српскословенски, рускословенски + српскословенски + српски народни и српскословенски + српски народни (Милановић 2005: 325). Пот-

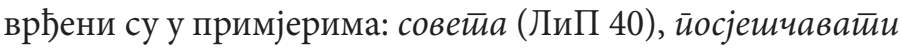

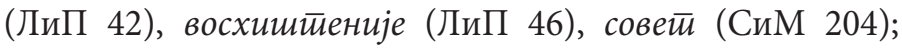
сохрағују (ЛуЋ 31), сохраненија (ЛуЋ 31), созаклейниизма (Лућ 50), совеитоваюа (72), возљубльено (Лућ 97), воздиже (ЛуЋ 148) и слично. ${ }^{4}$

Српски писци су, подвргавајући фонетској и морфолошкој адаптацији ријечи које нису карактеристичне за српски народни језик, стварали једну нову хибридну, тј. мјешовиту форму, која је у себи „усисавала” више различитих језичких нивоа - ниво рускословенског, српскословенског, руског књижевног језика и слично, и тако градила и правила славеносрбизме. „Током времена, употреба оваквих хибридних форми се 'не само стабилизовала већ су поменуте форме постајале одлика тог мешовитог типа књижевног језика који ми данас зовемо славеносрпски '” (Младеновић 1978: 110).

\section{3. Закључне напомене}

Мјесто и улога славенизама су различити у различитим књижевним формама. У комедији, превасходно кроз језик Алексе, славенизми, и то на лексичком нивоу, обиљежавају један тип људи - то је дакле језик којим се служе лажови, језик варалица и пробисвјета. Другим ријечима, Стерија је у уста варалица ставио славе-

4 Примјери су из прва два типа. 
носрпски, али не да исмије језик „језик којим се његови синови 'приближују богу' и који се 'не може надвисити богатством, простом виспреношћу, гипкости, пространством'” (Кићовић 1956: 341), него нешто друго. Преко језика он жели да исмије друштвене покондирености људи који се желе наметнути високим стилом. „Стерија је, према овоме, 'славенски' језик узео као језичко савршенство којим би разне варалице и незналице хтеле да се диче" (Кићовић 1956: 341). Дакле, у Лажи и йаралажи славенизми имају једну нову димензију - а то је да засмију, исмију и изазову комичне сцене. Потврда томе је и чињеница да Алексин језик није славеносрпски, како он узвишено жели, већ један неразуман и нејасан говор без

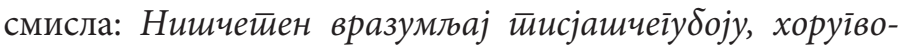
носјашчеју вешчестивеностиију (ЛиП 35). Зато Алекса и даје савјете како да се научи славенски: То је лако; само уйотиребльвај честио 'йонеже', 'gондеже' и йо неколико

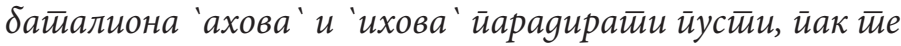
неће ни најбољи славјанин разуметии (ЛиП 36). Са друге стране, у трагедији Невиности или Светиислав и Милева славенизми дају једну додатну дозу префињености и узвишености. Другим ријечима, оне су ту да обогате књижевну баштину. Сви ликови говоре једним језиком, тј. своје особености не диференцирају диглосијом. Напротив и „добри” и „лоши” ликови говоре пробраним језиком. Како пише В. Каленић, Стеријин језик у трагедијама је извор хармоничности, док је у комедијама извор дисхармоничности (1981: 358).

У језику поезије савременог периода, славенизми имају сасвим нову димензију и функцију. Свој пјеснички идентитет Ного и Сладоје су управо градили на дијахроно обиљеженој лексици, посебно на славенизмима. Том лексиком појачавали су експресију свога израза и стила. Да би појачали ефектност израза, а и сачували неку древну лексику, Ного и Сладоје обогаћују свој рјечник лексе- 
мама црквенословенског поријекла (раб), српскословенског поријекла (чрева) и рускословенског поријекла (нишче̄). На тај начин продужавају живот сада неактивним ријечима српскога корпуса, а свој пјеснички језик чине препознатљивим и друкчијим. Исто тако је и језик Радована Белог Марковића богат овом дијахроном лексиком која је у функцији „наративног чарања”, „као бруј језичке енергије која се сама у себи ослобађа и својим ослобађањем истовремено омогућава да се и други слојеви прозног рукописа такође виде у неочекиваној и за наше књижевне прилике потпуно другачијој наративној перспективи од оне коју смо навикли. Радован Бели Марковић своју визију језички семантизованог прозног текста остварује и на макроструктуралном и на микроструктуралном плану” (Недић 2003: 91-92).

Дакле, као што смо и показали, удио славенизама у различитим књижевни формама је различит. Славенизми су имали и имају ширу употребу. Они су не само функционално везани за одређени пјеснички исказ, већ су улазили и улазе и данас у шири састав рјечничког блага нашег језика.

\section{Извори}

Марковић 2005: Радован Бели Марковић, Лимунација у Ћелијама, Бисери српске књижевности, књига број 40, Београд: Политика, Народна књига.

Ного 2010: Р. П. Ного, Не च̄икај у ме, допуњено издање, Београд: Београдска књига.

Поповић 1952: Јован Стерија Поповић, Драмска gела, Свеиислав и Милева, Београд: Народна библиотека „Жика Поповић”.

Поповић 1970: Јован Стерија Поповић, Комеgије, Лажа и йаралажа, књига 16, избор и предговор Милан Токин, Нови 
Сад: Српска књижевност у сто књига, штампарско предузеће „Будућност”.

Сладоје 2009: Ђорђо Сладоје, Манасииирски башӣован, Нови Сад: Фондација Матијевић, Београд: СКЗ.

\section{Литература}

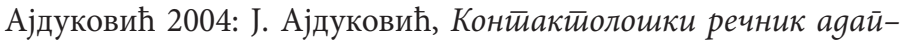
йације русизама, у осам словенских језика , Београд: Фото Футура.

Анђелковић 2003: С. Анђелковић, Сӣеријиних 80 комичних тикова, Вршац: КОВ.

Баук 2003: С. Баук, На размеђу језика и приче, Савремена срйска йроза, зборник број 15, Трстеник: Народна библиотека „Јефимија”.

Вукомановић 1988: С. Вукомановић, Вукова графија, ортографија и језик у рецензији „Новина сербских”, Научни сасиианак славистиа у Вукове gане, књ. 17. св. 2, Београд: МСЦ, Филолошки факултет.

Даничић 1863, 1864: Ђ. Даничић, Рјечник из књижевних стиарина срӣских, Биоград: Државна штампарија.

Зорић 2018: М. Зорић, Славенизми у раним драмама Јована Сӣерије Пойовића, Нови Сад: Матица српска.

Ивић 1998: П. Ивић, Преїлеg истиорије срӣскої језика, Сремски Карловци - Нови Сад: Издавачка књижарница Зорана Стојановића.

Јерковић 1991: Ј. Јерковић, Дијалектизми у Стеријиној прози, Језик и йисии, Нови Сад: Матица српска - Институт за јужнословенске језике Филозофског факултета.

Каленић 1981: В. Каленић, Хисторичност Стеријиног језика, Зборник Майице срйске за кюижевности и језик, XXIX/2, Нови Сад: Матица српска.

Караџић 1969: В. С. Караџић, Главне разлике између данашњега славенскога и српског језика, Сабрана gела Вука Каращића, књига осма, Даница 1826, приредио Милорад Павић, Београд: Просветиа. 
Караџић 1974: В. С. Караџић, Нови завјет господа нашега Исуса Христа, Сабрана gела Вука Каращића,књига Х, приредили Владимир Мошин и Димитрије Богдановић, Београд: Просветй

Кићовић 1956: М. Кићовић, Стерија и Вук Караџић, Кғиїа o С̄ерији, уредници Бранислав Миљковић и Милан Ђоковић, Београд: СКЗ.

Клаић 1972: Б. Клаић, Језичка проблематика у неким комедијама Јована Стерије Поповића, Зборник йрилоїа исӣорији јуїословенскоі̄ ӣозоришӣ $а$, Нови Сад: Српско народно позориште у Новом Саду.

Клајн, Шипка 2012: И. Клајн, М. Шипка, Велики речник сӣраних речи и израза, Нови Сад: Прометеј.

Милановић 2005: А. Милановић, Статус појма и термина славеносрбизам у лингвистици, Научни састианак слависииа у Вукове gане, 34/3, Београд: МСЦ, Филолошки факултет.

Младеновић 1978: А. Младеновић, О неким питањима и осо-

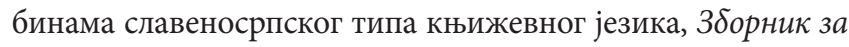
филолоїију и линіввисиичку XXI/1, Нови Сад: Матица српска. Младеновић 1979: А. Младеновић, Напомене о транскрипцији и критичком издавању старих српских текстова из XVIII и

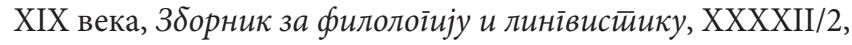
Нови Сад: Матица српска.

Младеновић 1982: А. Младеновић, Славеносрпски елементи у језику дела „Роман без романа” Јована Стерије Поповића, Зборник за филолоїчу и тинівистиику, XXV/1, Нови Сад: Матица српска.

Младеновић 1984. А. Младеновић, Прилоі йознавану значења 'славеносрйски језик' коg Срба у XVIII и у иррвој йоловини ХІХ века, сепарат.

Младеновић 1989: А. Младеновић, Славеносрӣски језик, Нови

Сад: Књижевна заједница Новог Сада - Дечје новине.

Недић 2003: М. Недић, Индивидуализација језика у савременој српској прози, Савремена срӣска йроза, зборник број 15, Трстеник: Народна библиотека „Јефимија”.

Пантић 2003: М. Пантић, Романи Радована Белог Марковића, Савремена срӣска йроза, зборник број 15, Трстеник: Народна библиотека „ефимија”. 
Петковић 1935: С. Петковић, Речник ирквенословенскої језика,

Сремски Карловци: Српска манастирска штампарија.

Продановић 2003: О. Продановић, Битак и привид у прозама

Радована Белог Марковића, Савремена срйска йроза, зборник број 15, Трстеник: Народна библиотека „Јефимија”.

Речник српског језика Матице српске 2007: Речник срӣскої језика Майиие срӣске, Нови Сад: Матица српска.

Самарџић 2011: Б. Самарџић, Славенизми у збирци „Не тикај у ме” Р. П. Нога, Наука и йолитичка, научни скупови, књига 5/1, Пале: Универзитет у Источном Сарајеву, Филозофски факултет.

СТАРОСЛОВЯНСКИЙ СЛОВАРЬ (По руКОПИСА̃м X - XI веков) 1994: СТАРОСЛОВЯНСКИЙ СЛОВАРЬ, Москва: ИНСТИТУТ СЛАВЯНОВЕДЕНИЯ И БАЛКАНИСТИКИ РОССИЙСКОЙ АКАДЕМИИ НАУК, СЛАВЯНСКИЙ ИНСТИТУТ АКАДЕМИИ НАУК ЧЕШСКОЙ РЕСПУБЛИКИ.

Стијовић 1992: С. Стијовић, Славенизми у Њеі̄ошевим йесничким gелима, Сремски Карловци, Нови Сад: Издавачка књижарница Зорана Стојановића.

Суботић 1989: Љ. Суботић, Језик Јована Хащића, Нови Сад: Матица српска.

Суботић 2006: Напомене о транскрипцији и језику рукописа Стеријиног незавршеног романа. Ј. Ст. Поповић, Дејан и Дамјанка или Паяеније босанскоі кралевсиива, приредили Љиљана Суботић и Сава Анђелковић, Вршац: КОВ.

Толстој 1977: Н. И. Толстој, Дискусија, Научни састианак слависйа у Вукове gане, књ. 6, св. 1, Београд: МСЦ, Филолошки факултет.

Унбегаун 1995: Б. Унбегаун, Почеци књижевног језика код Срба, Београд - Нови Сад: Вукова задужбина - Матица српска - Орфелин.

Шипка 1998: Д. Шипка, Основи тексиколоїије и сродних gисиийлина, Нови Сад: Матица српска. 
Самарджич Биляна

\section{МЕСТО СЛАВЯНИЗМОВ В ЯЗЫКЕ ЛИТЕРАТУРЫ}

В статье мы рассматривали роль и функцию славянизмов в различных литературных жанрах. Хотя славянизмы в современности не входят в активный корпус сербского языка, статья показала наблюдением и изучением славянизмов из различных литературных форм, что многие языковые выражения, которые появились в процессе эволюции из форм сербскославянского и русскославянского/церковнославянского и таким способом обогатили язык литературы в период до Вука Стефановича Караджича но и в сегодняшнее время, „живут” и обогащают сербский языковой корпус и являются частью языка литературы. Термин „славянизм” в нашем тексте обозначает слова славянского происхождения, которые принадлежат русскославянскому, русскому литературному, славянскосербскому и сербскославянскому языкам но не принадлежат сербскому народному языку.

Ключевые слова: славянизмы, литературный язык, язык литературы 